\title{
Proposed Constitution Amendment
}

Following is the text of the proposed amendment to the InterCollege Court Constitution.-Ed.

it

The Inter-College Court shall have no jurisdiction over an individual, except in the following two circumstances: in offenses involving individual members of more than one college; and in offenses of all school importance that does not involve the individual in his zosition as a college member. The chairman of the Inter6. College Court and the chief justice of the individual's college will decide when the latter provision is in effect. 